\title{
Cigarette smoke extract induced exosome release is mediated by depletion of exofacial thiols and can be inhibited by thiol-antioxidants
}

Citation for published version (APA):

Benedikter, B. J., Volgers, C., van Eijck, P. H., Wouters, E. F. M., Savelkoul, P. H. M., Reynaert, N. L., Haenen, G. R. M. M., Rohde, G. G. U., Weseler, A. R., \& Stassen, F. R. M. (2017). Cigarette smoke extract induced exosome release is mediated by depletion of exofacial thiols and can be inhibited by thiolantioxidants. Free Radical Biology and Medicine, 108, 334-344.

https://doi.org/10.1016/j.freeradbiomed.2017.03.026

Document status and date:

Published: 01/07/2017

DOI:

10.1016/j.freeradbiomed.2017.03.026

Document Version:

Publisher's PDF, also known as Version of record

\section{Document license:}

Taverne

Please check the document version of this publication:

- A submitted manuscript is the version of the article upon submission and before peer-review. There can be important differences between the submitted version and the official published version of record.

People interested in the research are advised to contact the author for the final version of the publication, or visit the DOI to the publisher's website.

- The final author version and the galley proof are versions of the publication after peer review.

- The final published version features the final layout of the paper including the volume, issue and page numbers.

Link to publication

\footnotetext{
General rights rights.

- You may freely distribute the URL identifying the publication in the public portal. please follow below link for the End User Agreement:

www.umlib.nl/taverne-license

Take down policy

If you believe that this document breaches copyright please contact us at:

repository@maastrichtuniversity.nl

providing details and we will investigate your claim.
}

Copyright and moral rights for the publications made accessible in the public portal are retained by the authors and/or other copyright owners and it is a condition of accessing publications that users recognise and abide by the legal requirements associated with these

- Users may download and print one copy of any publication from the public portal for the purpose of private study or research.

- You may not further distribute the material or use it for any profit-making activity or commercial gain

If the publication is distributed under the terms of Article $25 \mathrm{fa}$ of the Dutch Copyright Act, indicated by the "Taverne" license above, 
Original article

\title{
Cigarette smoke extract induced exosome release is mediated by depletion of exofacial thiols and can be inhibited by thiol-antioxidants
}

\author{
Birke J. Benedikter ${ }^{\mathrm{a}, \mathrm{b}}$, Charlotte Volgers ${ }^{\mathrm{a}}$, Pascalle H. van Eijck ${ }^{\mathrm{a}}$, Emiel F.M. Wouters ${ }^{\mathrm{b}}$, \\ Paul H.M. Savelkoul ${ }^{\mathrm{a}, \mathrm{d}}$, Niki L. Reynaert ${ }^{\mathrm{b}}$, Guido R.M.M. Haenen ${ }^{\mathrm{c}}$, Gernot G.U. Rohde ${ }^{\mathrm{b}}$, \\ Antje R. Weseler ${ }^{\mathrm{c}, 1}$, Frank R.M. Stassen ${ }^{\mathrm{a}, *, 1}$ \\ a Department of Medical Microbiology, Maastricht University Medical Center, PO Box 5800, 6202 AZ Maastricht, The Netherlands \\ ${ }^{\mathrm{b}}$ Department of Respiratory Medicine, Maastricht University Medical Center, PO Box 5800, 6202 AZ Maastricht, The Netherlands \\ c Department of Pharmacology and Toxicology, Maastricht University, PO Box 616, 6200 MD Maastricht, The Netherlands \\ d Department of Medical Microbiology \& Infection Control, VU University Medical Center, Van der Boechorststraat 7, 1081BT Amsterdam, The Netherlands
}

\section{A R T I C L E I N F O}

\section{Keywords:}

Extracellular vesicles

EV

COPD

Lung

Chronic inflammation

Oxidative stress

Acrolein

DTNB

Airway epithelial cells

\begin{abstract}
A B S T R A C T
Introduction: Airway epithelial cells have been described to release extracellular vesicles (EVs) with pathological properties when exposed to cigarette smoke extract (CSE). As CSE causes oxidative stress, we investigated whether its oxidative components are responsible for inducing EV release and whether this could be prevented using the thiol antioxidants N-acetyl-L-cysteine (NAC) or glutathione (GSH).

Methods: BEAS-2B cells were exposed for $24 \mathrm{~h}$ to CSE, $\mathrm{H}_{2} \mathrm{O}_{2}$, acrolein, 5,5'-dithiobis-(2-nitrobenzoic acid) (DTNB), bacitracin, rutin or the anti-protein disulfide isomerase (PDI) antibody clone RL90; with or without NAC or GSH. EVs in media were measured using $\mathrm{CD} 3^{+} \mathrm{CD} 81^{+}$bead-coupled flow cytometry or tunable resistive pulse sensing (TRPS). For characterization by Western Blotting, cryo-transmission electron microscopy and TRPS, EVs were isolated using ultracentrifugation. Glutathione disulfide and GSH in cells were assessed by a GSH reductase cycling assay, and exofacial thiols using Flow cytometry.

Results: CSE augmented the release of the EV subtype exosomes, which could be prevented by scavenging thiolreactive components using NAC or GSH. Among thiol-reactive CSE components, $\mathrm{H}_{2} \mathrm{O}_{2}$ had no effect on exosome release, whereas acrolein imitated the NAC-reversible exosome induction. The exosome induction by CSE and acrolein was paralleled by depletion of cell surface thiols. Membrane impermeable thiol blocking agents, but not specific inhibitors of the exofacially located thiol-dependent enzyme PDI, stimulated exosome release.

Summary/conclusion: Thiol-reactive compounds like acrolein account for CSE-induced exosome release by reacting with cell surface thiols. As acrolein is produced endogenously during inflammation, it may influence exosome release not only in smokers, but also in ex-smokers with chronic obstructive pulmonary disease. NAC and GSH prevent acrolein- and CSE-induced exosome release, which may contribute to the clinical benefits of NAC treatment.
\end{abstract}

\section{Introduction}

Situated at the vast interface between environment and lung tissue, the airway epithelium is crucial for maintaining pulmonary home- ostasis. Not only does it act as a physical barrier, it also supports appropriate responses to inhaled pathogens and chemicals by sending signals towards immune and stromal cells in its vicinity (for a review, see [1]). Yet, epithelial integrity and function become impaired upon

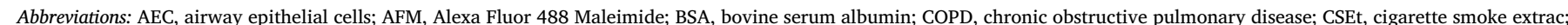

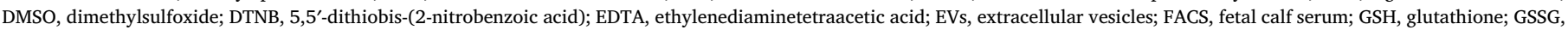

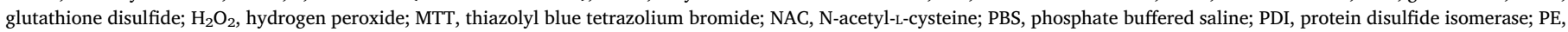
phycoerythrin; PI, propidium iodide; RFU, relative fluorescence units; ROS, reactive oxygen species; TRPS, tunable resistive pulse sensing

* Corresponding author.

E-mail addresses: b.benedikter@maastrichtuniversity.nl (B.J. Benedikter), c.volgers@maastrichtuniversity.nl (C. Volgers), pascallevaneijck@gmail.com (P.H. van Eijck), e.wouters@mumc.nl (E.F.M. Wouters), paul.savelkoul@mumc.nl (P.H.M. Savelkoul), n.reynaert@maastrichtuniversity.nl (N.L. Reynaert), g.haenen@maastrichtuniversity.nl (G.R.M.M. Haenen), g.rohde@mumc.nl (G.G.U. Rohde), a.weseler@maastrichtuniversity.nl (A.R. Weseler), f.stassen@maastrichtuniversity.nl (F.R.M. Stassen).

${ }^{1}$ These authors contributed equally. 
chronic exposure to noxious stimuli, for instance in long term cigarette smokers [2]. Cigarette smoke-induced epithelial damage is partly mediated by components that cause oxidative stress, such as the reactive oxygen species (ROS) hydrogen peroxide $\left(\mathrm{H}_{2} \mathrm{O}_{2}\right)[3,4]$ and the reactive carbonyl acrolein $[5,6]$. The oxidative stress exerted by cigarette smoke components is thought to contribute to the early pathogenesis of chronic obstructive pulmonary disease (COPD) [7]. Moreover, once COPD is established, markers of oxidative stress, as well as acrolein, remain elevated in the lungs even after patients stop smoking $[8,9]$. Recent studies have revealed that treatment with a highdose of the thiol-group bearing mucolytic and antioxidant N-acetyl-Lcysteine (NAC) improved small airway function in COPD patients [10] and lowered the frequency of acute exacerbations [11]. This suggests that oxidative stress causally contributes to small airway disease and worsening of COPD via acute exacerbations, even in ex-smokers.

A number of studies have suggested that oxidative stress influences the release of extracellular vesicles (EVs) by various cell types [12-14]. EVs are membrane vesicles secreted by nearly all cell types. They consist of a lipid bilayer surrounding an aqueous lumen, and act as carriers for molecules derived from their cell of origin, including membrane proteins, cytoplasmic proteins and RNA. EV functions include removing unnecessary or toxic molecules from their cell of origin $[15,16]$, as well as delivering complex messages between cells [17]. Thus, EVs regulate many biological processes, including immune responses and inflammation [17]. Although EV nomenclature is complex and still controversial [18], EVs are commonly classified into two major groups based on their size and marker expression, the larger microvesicles and the smaller exosomes. In the context of cigarette smoke-induced lung disease, microvesicles have been studied predominantly to evaluate their utility as biomarkers for early lung damage and exacerbation susceptibility $[19,20]$. In contrast, the smaller exosomes have been investigated for functional properties that may contribute to COPD pathogenesis. Two recent in vitro studies have suggested that exosomes secreted by airway epithelial cells (AEC) exposed to cigarette smoke extract (CSE) cause inflammation [21] and tissue remodeling by inhibiting fibroblast autophagy [22]. Yet, it has not been clarified how CSE influences the exosome release by AEC and whether this can be manipulated. We hypothesized that oxidative CSE components, such as $\mathrm{H}_{2} \mathrm{O}_{2}$ or acrolein, mediate CSE-induced exosome release and that the exosome induction can be prevented by antioxidants.

\section{Materials and methods}

\subsection{Cell culture}

BEAS-2B human bronchial epithelial cells (ATCC CRL-9609) were cultured at $5 \% \mathrm{CO}_{2}$ and $37^{\circ} \mathrm{C}$ in T-75 culture flasks pre-coated with LHC basal medium (Gibco, Life Technologies, New York, NY, USA) supplemented with $0.1 \mathrm{mg} / \mathrm{ml}$ bovine serum albumin (BSA, Boehringer Mannheim GmbH, Mannheim, Germany), $0.03 \mathrm{mg} / \mathrm{ml}$ bovine collagen I (BD Biosciences, San Jose, CA, USA) and $0.01 \mathrm{mg} / \mathrm{ml}$ human fibronectin (BD Biosciences). Cells were subcultured twice per week in RPMI1640 (Gibco) containing 10\% fetal calf serum (FCS, Lonza, Verviers, Belgium).

\subsection{EV-depletion of FCS}

To deplete confounding bovine EVs, FCS was diluted to $30 \%(\mathrm{v} / \mathrm{v})$ in DMEM-F12 without phenol-red (Gibco) and centrifuged for $16 \mathrm{~h}$ at $40,000 \mathrm{rpm}$ (Average RCF $=117,734 \times g$ ), in a fixed-angle Type 70Tirotor in an Optima L-90K preparative ultracentrifuge (BeckmanCoulter, Brea, CA, USA). The supernatant was collected without disturbing the concentrated layer at the bottom of the tube.

\subsection{Stimuli and cell exposures}

$\mathrm{N}$-acetyl-L-cysteine (NAC), $\mathrm{H}_{2} \mathrm{O}_{2}$, acrolein, 5,5'-dithiobis-(2-nitrobenzoic acid) (DTNB), bacitracin and rutin were from Sigma Aldrich (St. Louis, MO, USA). The monoclonal anti-protein disulfide isomerase (PDI) antibody clone RL90 was from Thermo Fisher Scientific (Waltham, MA, USA). To produce CSE, mainstream smoke of one cigarette (Reference Cigarette 3R4F, Tobacco-Health Research, University of Kentucky, USA) without filter was drawn through $2 \mathrm{ml}$ phosphate buffered saline (PBS) using a vacuum-pump at constant speed. The obtained solution was filtered through a $0.22 \mu \mathrm{m}$ Acrodisk filter (Pall, Port Washington, NY, USA) and defined as 100\% CSE. For quality control, the extinction of $100 \mu 1100 \%$ CSE was measured in duplicate at wavelengths of $\lambda=320 \mathrm{~nm}$ (A320) and $\lambda=540 \mathrm{~nm}$ (A540). CSE quality was accepted if $\triangle$ OD (A320-A540) was between 0.9 and 1.2. CSE was prepared freshly for each experiment and used within $15 \mathrm{~min}$.

BEAS-2B cells were seeded in RPMI $1640+10 \%(\mathrm{v} / \mathrm{v})$ FCS on precoated plates $\left(5 \times 10^{4}\right.$ cells $\left./ \mathrm{cm}^{2}\right)$ and allowed to attach for $24 \mathrm{~h}$. Cells were washed twice with PBS and incubated with reduction medium (DMEM-F12 + 0.1\% (v/v) EV-depleted FCS, $0.25 \mathrm{ml} / \mathrm{cm}^{2}$ ) for $2 \mathrm{~h}$. Next, cells were exposed to different concentrations of CSE, acrolein, $\mathrm{H}_{2} \mathrm{O}_{2}$, DTNB, bacitracin, rutin or RL90 in reduction medium for $24 \mathrm{~h}$. Where indicated, cells were treated with NAC $(1 \mathrm{mM})$ or GSH $(62.5,125$ or $250 \mu \mathrm{M}$ ) for $2 \mathrm{~h}$. After these $2 \mathrm{~h}$, cells were washed with PBS to remove any pre-formed EVs. Then, NAC or GSH were added again to the cells in combination with either CSE, acrolein or $\mathrm{H}_{2} \mathrm{O}_{2}$ and co-incubated for $24 \mathrm{~h}$. Rutin was dissolved in DMSO, all other chemicals were dissolved and diluted in PBS. Vehicle controls were exposed to matched concentrations of DMSO or PBS. The vehicle control for RL90 contained $0.0005 \%(\mathrm{v} / \mathrm{v})$ sodium azide.

\subsection{MTT assay}

Cells were washed with PBS and $200 \mu \mathrm{l} / \mathrm{cm}^{2}$ reduction medium containing $0.5 \mathrm{mg} / \mathrm{ml}$ thiazolyl blue tetrazolium bromide (MTT; Sigma Aldrich) was added. After $3 \mathrm{~h}$, medium was discarded and the formed formazan crystals were dissolved in $100 \mu \mathrm{l} / \mathrm{cm}^{2}$ dimethyl sulfoxide (DMSO; Sigma Aldrich). Absorbance of the dissolved formazan was measured at $\lambda=540 \mathrm{~nm}$ and cell viability was expressed relative to a non-treated cells $(100 \%$ cell viability) and triton-lysed cells $(0 \%$ viability).

\subsection{GSH measurements}

For determining GSH oxidation in cell-free conditions, different CSE dilutions were made in PBS containing $50 \mu \mathrm{M}$ reduced glutathione (Sigma Aldrich) and incubated for $24 \mathrm{~h}$ at $37^{\circ} \mathrm{C}$. Ten microliter of each solution was transferred to a 96-well plate in triplicate. Ninety microliter of DTNB working reagent (1 mM DTNB and $2.5 \mathrm{mM}$ sodium acetate in $0.1 \mathrm{M}$ Tris-hydrochloride, $\mathrm{pH}$ 8.8) was then added. Absorbance was measured with a plate reader at $\lambda=412 \mathrm{~nm}$.

For analyzing cellular GSH concentrations, $2 \times 10^{5}$ cells were washed twice with ice cold PBS. They were then incubated on ice with $250 \mu \mathrm{l} 0.1 \mathrm{M}$ potassium phosphate buffer containing $5 \mathrm{mM}$ ethylenediaminetetraacetic acid (EDTA) disodium salt and $0.1 \%(\mathrm{v} / \mathrm{v})$ Triton X$100, \mathrm{pH}=7.5$ for $30 \mathrm{~min}$. Next, cells were scraped and cellular debris was pelleted at $16,100 \times g$ at $4{ }^{\circ} \mathrm{C}$ for $15 \mathrm{~min}$. Supernatant was transferred to a new tube. Protein concentrations were determined using the Bradford assay according to the manufacturer's protocol (BioRad, Hercules, CA, USA). The remaining supernatant was mixed 1:1 with $6 \%(\mathrm{~m} / \mathrm{v})$ sulfosalicylic acid. The samples were stored at $-80{ }^{\circ} \mathrm{C}$ until analysis of GSH and the GSH oxidation product glutathione disulfide (GSSG) using an enzymatic cycling assay as previously described [23]. GSSG and GSH concentrations were normalized to the protein concentrations. 


\subsection{Quantification of exofacial thiol groups}

Cells $\left(2 \times 10^{5}\right)$ were washed $3 \times$ with PBS and incubated for $10 \mathrm{~min}$ with $2 \mathrm{mM}$ EDTA in PBS before gentle scraping. Detached cells were pelleted at $400 \times g$ for $7 \mathrm{~min}$ at $4{ }^{\circ} \mathrm{C}$ and resuspended in PBS. Alexa Fluor $^{\circledR} 488$ C5 Maleimide (AFM; Thermo Fisher Scientific, Waltham, MA, USA) was added to the homogenous cell suspension to a final concentration of $2.5 \mu \mathrm{M}$, followed by $15 \mathrm{~min}$ incubation on ice. Cells were pelleted again $\left(400 \times g, 7 \mathrm{~min}, 4^{\circ} \mathrm{C}\right)$, washed with PBS, followed by a last centrifugation $\left(400 \times g, 7 \mathrm{~min}, 4^{\circ} \mathrm{C}\right)$. For flow cytometry measurements using a BD FACSCanto and FACS Diva V8.0.1 software (BD Biosciences), cells were resuspended in PBS containing 1\% $(\mathrm{w} / \mathrm{v})$ bovine serum albumin (BSA; Sigma Aldrich). Just before measuring, $1 \mu \mathrm{g} / \mathrm{ml}$ propidium iodide (PI; Sigma Aldrich) was added in order to gate out cells with impaired membrane integrity. The relative quantity of exofacial thiol groups was determined as the median fluorescence intensity of AFM in the PI-low cell population.

\subsection{Processing conditioned cell culture medium}

Conditioned medium of BEAS-2B cells $(1 \mathrm{ml}$ per condition for EV measurements using bead-coupled flow cytometry, $40 \mathrm{ml}$ for EV isolation using ultracentrifugation) was centrifuged at $300 \times g$ for $10 \mathrm{~min}$ at $4{ }^{\circ} \mathrm{C}$ to pellet cells, then at $5000 \times g$ for $10 \mathrm{~min}$ at $4{ }^{\circ} \mathrm{C}$ to pellet cell debris. Where indicated, the conditioned medium was filtered through a $0.22 \mu \mathrm{m}$ filter to remove larger membrane vesicles. Conditioned medium was always processed within one day without any freeze-thaw cycles.

\subsection{Analysis of EV release using bead-coupled flow cytometry}

EV detection using bead-coupled flow cytometry was performed as described previously [24,25], with some adaptations: $3.5 \times 10^{8}$ beads/ $\mathrm{ml}(4 \mu \mathrm{M}$ aldehyde/sulfate latex beads $5 \%(\mathrm{w} / \mathrm{v})$; Molecular Probes Life Technologies, Waltham, MA, USA) were coated with $0.125 \mathrm{mg} / \mathrm{ml}$ mouse anti-human CD63 antibody (Clone H5C6; BD Biosciences) by overnight incubation in MES buffer. These beads were stored in PBS containing $0.1 \%(\mathrm{~m} / \mathrm{v})$ glycine and $0.1 \%(\mathrm{~m} / \mathrm{v})$ sodium azide at $4^{\circ} \mathrm{C}$ until use. For EV-coupling, $2 \times 10^{5} \mathrm{CD} 63$-coated beads were incubated with $400 \mu \mathrm{l}$ conditioned medium overnight. Beads were then washed twice with PBS containing $2 \%(\mathrm{~m} / \mathrm{v})$ BSA by centrifugation at $5000 \times g$ for $10 \mathrm{~min}$. The bead pellet was resuspended in $50 \mu \mathrm{l}$ PBS-2\% (m/v) BSA containing $0.01 \mathrm{mg} / \mathrm{ml}$ phycoerythrin (PE)-labeled mouse antihuman CD81 antibody (Clone JS-81; BD Biosciences) and incubated for $1 \mathrm{~h}$. Beads were washed twice with PBS $-2 \%(\mathrm{~m} / \mathrm{v})$ BSA by centrifugation at $5000 \times g$ for $10 \mathrm{~min}$. The final bead pellet was resuspended in $200 \mu \mathrm{l}$ PBS and analyzed by flow cytometry using a BD FACSCanto (BD Biosciences) with FACS Diva V8.0.1 software (BD Biosciences). All incubations were carried out at room temperature and with vigorous shaking $\left(1000 \mathrm{~min}^{-1}\right)$. The quantity of EVs in relative fluorescent units (RFU) was calculated by multiplying the percentage of PE-positive beads with the median fluorescent intensity (MFI) of the positive bead population.

\subsection{EV analysis using tunable resistive pulse sensing (TRPS)}

TRPS was performed using a qNano Gold with Izon Control Suite 3.2 Software and CPC100 calibration beads (Izon, Chirstchurch, New Zealand). Cell-depleted unfiltered medium was analyzed after a single freeze-thaw cycle at $-80^{\circ} \mathrm{C}$. An NP150 nanopore (Izon) was coated using the Izon reagent kit for $\mathrm{EV}$ analysis according to the manufacturer's instructions. To obtain a stable baseline current, samples were diluted 1:2 in Solution Q (Izon) and to prevent frequent pore obstruction, 10\% (v/v) Solution G (Izon) was added. The NP150 nanopore was used at a stretch of $45-47 \mathrm{~mm}$ and a pressure of 10-12 mbar, keeping the current between 120 and $130 \mathrm{nA}$ for all measurements. Recordings were stopped after detection of 500 blockades or after $10 \mathrm{~min}$.

\subsection{EV isolation using ultracentrifugation}

Cell-depleted medium ( $40 \mathrm{ml} /$ condition) was filtered through an Acrodisk $0.22 \mu \mathrm{m}$ filter (Pall) to remove larger membrane vesicles or particles. The filtered medium was centrifuged in an Optima L-90K preparative ultracentrifuge (Beckman-Coulter) using a fixed-angle Type 70Ti-rotor (Beckman-Coulter) and QuickSeal tubes (Ultra-Clear, $39 \mathrm{ml}$, Beckman-Coulter) at 40,000 rpm (Average RCF $=117,734 \times g$ ) for $2.5 \mathrm{~h}$ (optimal speed and duration as determined by Cvjetkovic et al. [26]). After ultracentrifugation, supernatant was poured off and the invisible EV-pellet was resuspended in $70 \mu \mathrm{l}$ PBS for cryo-TEM, $70 \mu \mathrm{l}$ lysis buffer $(1.5 \%(\mathrm{~m} / \mathrm{v})$ sodium dodecyl sulfate (SDS), $50 \mathrm{mM}$ Tris, $\mathrm{pH}=6.8)$ for Western blotting, or in $2.5 \mathrm{ml}$ DMEM-F12+0.1\% (v/v) EV-depleted FCS for flow cytometric analysis. For cyro-TEM and flow cytometric analysis, isolated EVs were processed immediately. For Western blotting, samples were stored in lysis buffer at $-80^{\circ} \mathrm{C}$ until gel electrophoresis was performed.

\subsection{Western blotting}

Sodium dodecyl sulfate polyacrylamide gel electrophoresis (SDSPAGE) was performed according to standard protocol, with a $12 \%$ running gel. Before loading, the protein concentration of all cell and EV lysates was standardized and samples were diluted 1:2 in $2 \times$ XT sample buffer (Bio-Rad) containing $5 \mathrm{M}$ urea and cOmplete ${ }^{\mathrm{TM}}$ protease inhibitor cocktail (Roche Life Science, Penzberg, Germany) at the concentration recommended by the manufacturer. Blots were stained for $2-3 \mathrm{~h}$ with $0.5 \mu \mathrm{g} / \mathrm{ml}$ mouse anti-human CD63 antibody (Clone H5C6; BD Biosciences), followed by $1 \mathrm{~h}$ incubation with HRP-conjugated rabbit anti-mouse antibody diluted 1:1000 (P0260; DAKO, Agilent Technologies, Santa Clara, CA, USA). The blots were incubated with chemiluminescent peroxidase substrate-3 (Sigma Aldrich) and signal was detected using an enhanced chemiluminescence system (ChemiDoc $^{\mathrm{TM}}$ MP System, Bio-Rad).

\subsection{Cryo-transmission electron microscopy}

To prepare vitrified EV specimens, a freshly glow-discharged Quantifoil R 2/2 grid (Quantifoil Micro Tools GmbH, Jena, Germany) was loaded into a FEI Mark IV Vitrobot (FEI Company, Eindhoven, The Netherlands). The Vitrobot environmental chamber was maintained at $22{ }^{\circ} \mathrm{C}$ and $100 \%$ humidity. Three microliter of freshly isolated EV suspension was added to the grid. The grid was blotted immediately for $1 \mathrm{~s}$ before plunge-freezing in liquid ethane $\left(-180^{\circ} \mathrm{C}\right)$. For microscopy, grids were mounted in a Gatan cryoholder (Gatan, Pleasanton, CA, USA) in liquid nitrogen and images were acquired at $120 \mathrm{kV}$ using a Tecnai Biotwin iCorr 120KV (FEI Company).

\subsection{Statistics}

All data are composed of at least three independent experiments. Data were analyzed with Graphpad Prism software (GraphPad Software, Inc., La Jolla, CA, USA). Because of the small sample size and the paired nature of the data, data was analyzed using the nonparametric Wilcoxon matched-pairs signed rank test (where 2 groups were compared) or the non-parametric Friedman test, followed by Dunn's posthoc test (where more than 2 groups were compared) unless indicated differently. P-values below 0.05 were considered statistically significant. Values in the text are given as the median and interquartile range (IQR). 
A
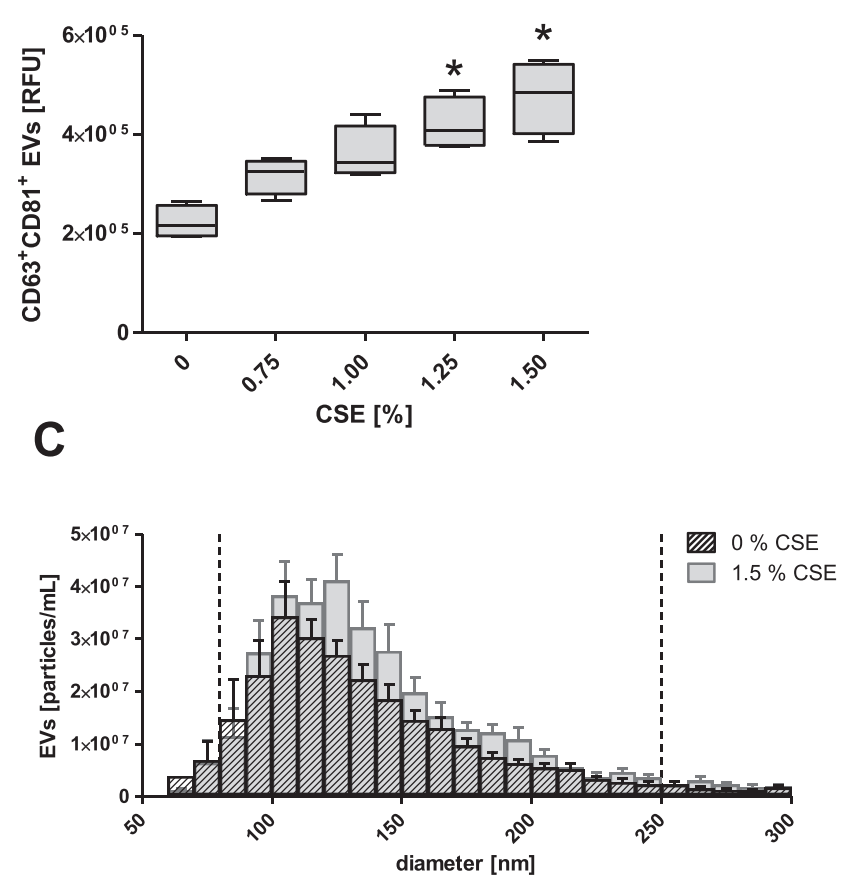

E

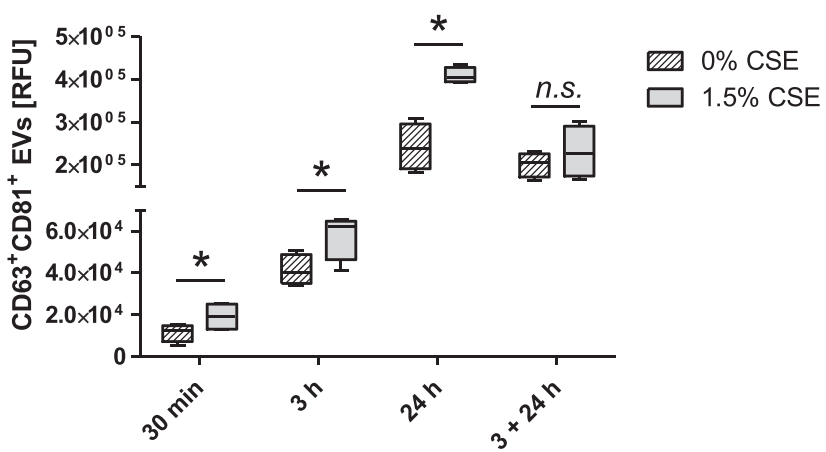

B
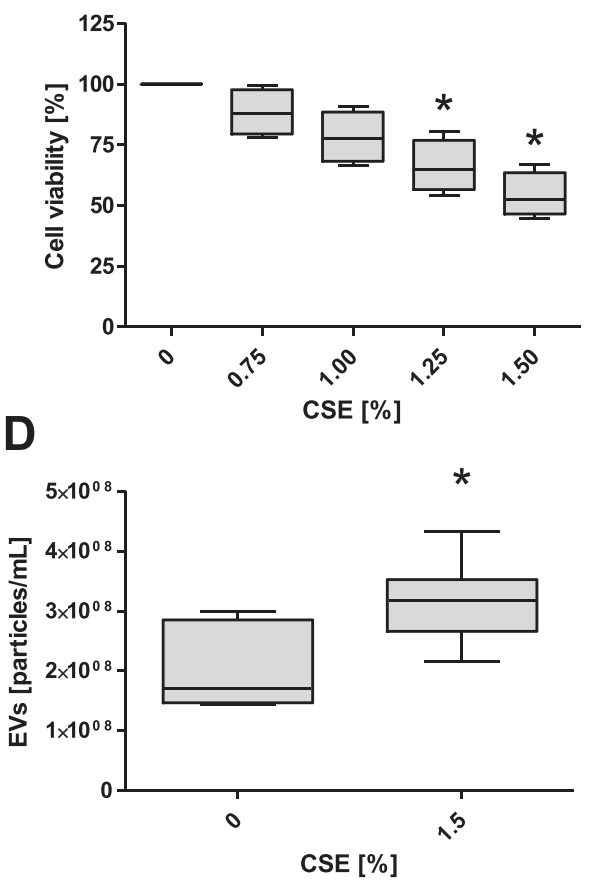

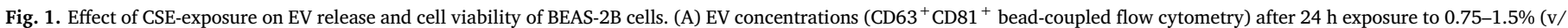

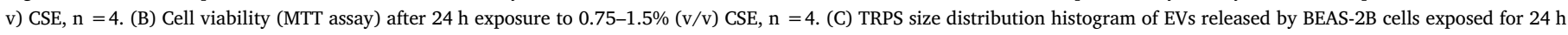

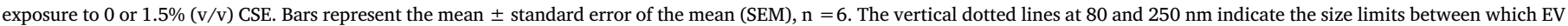

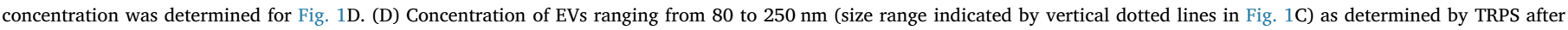

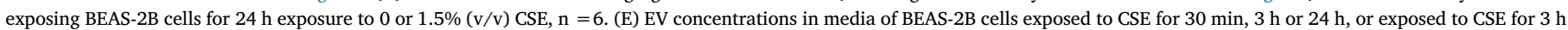

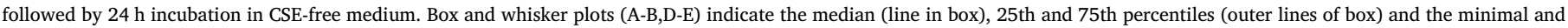

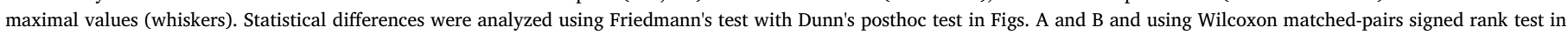
figure D (*p $<0.05$ compared with $0 \% \mathrm{CSE}$ ).

\section{Results}

3.1. CSE exposure enhances the release of EVs with exosome properties by $A E C$

To determine the effect of CSE-exposure on EV release by AEC, BEAS-2B cells were exposed to CSE concentrations ranging from $0.75 \%$ to $1.5 \%(\mathrm{v} / \mathrm{v})$ for $24 \mathrm{~h}$. The quantity of $\mathrm{CD} 63^{+} \mathrm{CD} 81^{+} \mathrm{EVs}$ in the conditioned media was assessed using bead-coupled flow cytometry. A concentration-dependent increase in EV release was observed from 1.4 fold (IQR 1.3-1.6) at $0.75 \%$ CSE up to 2.3 fold (IQR 1.6-2.7) at $1.5 \%$ CSE (Fig. 1A). This was associated with a decrease in cell viability ranging from $88.0 \%$ (IQR 79.6-97.6) cell viability at $0.75 \%$ CSE to $52.7 \%$ (IQR 46.5-63.5) at $1.5 \%$ CSE (Fig. 1B). Using TRPS, we confirmed an increased concentration of small EVs $(80-250 \mathrm{~nm}$ in diameter) after $24 \mathrm{~h}$ exposure to $1.5 \%$ (v/v) CSE (Fig. 1C, D). The EV induction was fast and sustained, as the EV concentration was increased for CSE-exposed cells at $30 \mathrm{~min}, 3 \mathrm{~h}$ and $24 \mathrm{~h}$ (Fig. 1E). Moreover, the induction required the continuous presence of CSE, as there was no increased EV concentration compared to the unexposed control when cells were stimulated with CSE for $3 \mathrm{~h}$, followed by washing and $24 \mathrm{~h}$ incubation in CSE-free medium (Fig. 1E).

The tetraspanins CD63 and CD81, which we used for flow cytometric EV detection, are classically considered specific marker proteins for the smallest EV type, exosomes [27]. However, it has recently been suggested that the larger microvesicles may express these proteins as well [28]. To determine whether the EVs detected by $\mathrm{CD} 63^{+} \mathrm{CD} 81^{+}$ flow cytometry were truly exosomes, we first determined their size by comparing the flow cytometry signal in non-filtered media with the signal in media passed through a $0.22 \mu \mathrm{m}$ filter. Signal recovery after filtration was complete for both control and CSE-induced EVs (Fig. 2A), suggesting that the vast majority of EVs detected using bead-coupled flow cytometry was smaller than $220 \mathrm{~nm}$. We also determined the size distribution of EVs in unfiltered conditioned media using TRPS. The mode size was about $100 \mathrm{~nm}$ for both, control EVs and CSE EVs, with the majority of particles being smaller than $200 \mathrm{~nm}$ (Fig. 1C). One of 

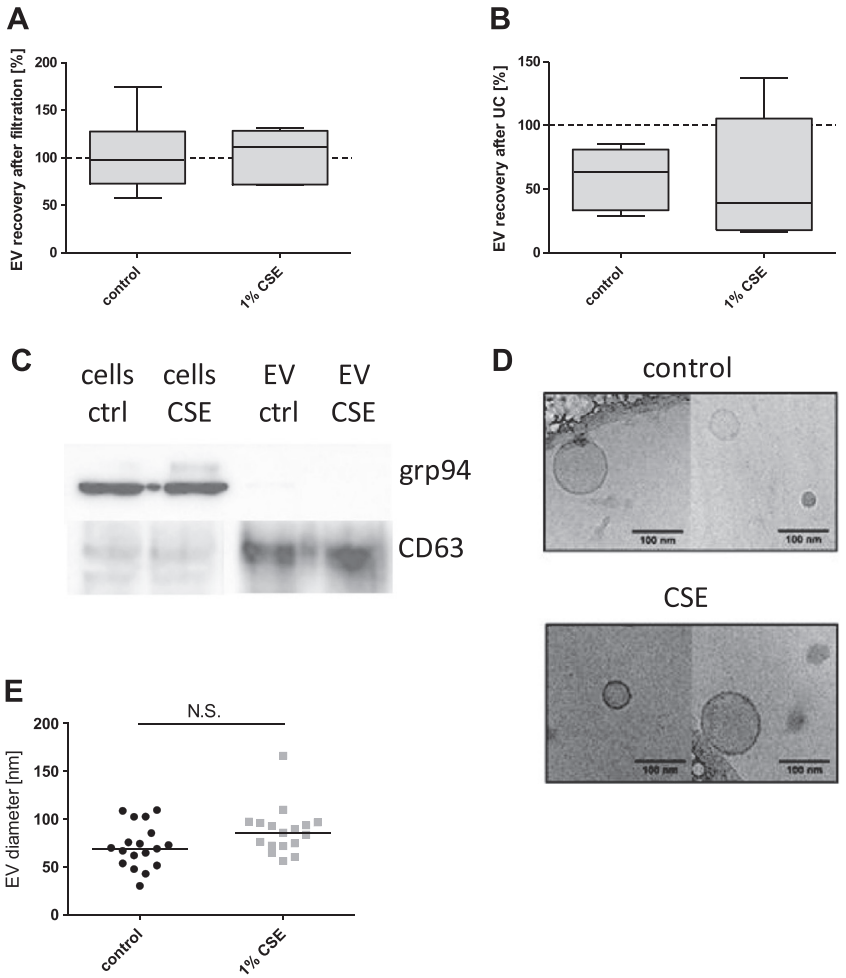

Fig. 2. Characterization of EVs released by BEAS-2B cells after $24 \mathrm{~h}$ exposure to 0 or $1 \%$ (v/v) CSE. (A) Quantity of EVs detected using bead-coupled flow cytometry for $\mathrm{CD} 63{ }^{+} \mathrm{CD} 81^{+} \mathrm{EVs}$ in conditioned medium before and after $0.22 \mu \mathrm{m}$-filtration; $\mathrm{n}=7$. (B) Recovery of EVs by ultracentrifugation, estimated using bead-coupled flow cytometry for $\mathrm{CD} 63{ }^{+} \mathrm{CD} 81^{+} \mathrm{EVs} ; \mathrm{n}=5$. (C) Western blots of EVs isolated by ultracentrifugation. Blots were stained for endoplasmic reticulum-derived contamination marker grp94 and exosome marker CD63. (D) Cryo-TEM of EVs. The scale bars are $100 \mathrm{~nm}$. (E) EV diameter according to cryo-TEM (horizontal bars indicate the median; $\mathrm{n}=18$ for control EVs and $\mathrm{n}$ $=17$ for CSE EVs). Statistical differences in EV diameter were analyzed using the MannWhitney test (N.S. = not significant). Box and whisker plots (A-B) indicate the median (line in box), 25th and 75th percentiles (outer lines of box) and the minimal and maximal values (whiskers)

the most commonly applied isolation protocols for small EVs is $0.22 \mu \mathrm{m}$ filtration of conditioned cell culture medium followed by ultracentrifugation at high speed $($ e.g. $120,000 \times g)$. Using this protocol, a large fraction of $\mathrm{CD} 3^{+} \mathrm{CD} 81^{+}$EVs measured in the conditioned medium could be recovered both for control EVs (63.4\%, IQR 33.4-80.9\%) and CSE-induced EVs (39.3\%, IQR 17.7-105.4\%) (Fig. 2C). Western blotting confirmed the presence of CD63 in the ultracentrifugation isolate from both exposure conditions, whereas the endoplasmic reticulum-derived contamination marker grp94 was undetectable (Fig. 2D). Finally, cryoTEM of isolated control EVs and CSE EVs revealed membrane surrounded spheres ranging from 30 to $170 \mathrm{~nm}$ in diameter (Fig. 2E, F). Based on the properties described in this paragraph, we will from now on refer to the EVs in this study as exosomes.

\subsection{The exosome induction is mediated by CSE components that react with} thiol groups and is prevented by clinically relevant concentrations of thiolantioxidants

To confirm that CSE contains oxidative components, CSE was incubated with the thiol group bearing antioxidant GSH. This resulted in a concentration-dependent depletion of free GSH (data not shown). Next, to investigate whether the oxidative components of CSE were causally responsible for the exosome induction, AEC were exposed to CSE in the absence or presence of the antioxidant NAC. NAC completely prevented CSE-induced exosome release as determined by $\mathrm{CD} 63^{+} \mathrm{CD} 81^{+}$bead-coupled flow cytometry (Fig. 3A) and by TRPS (Fig. 3B). It also prevented the decrease in cell viability (Fig. 3C).
A
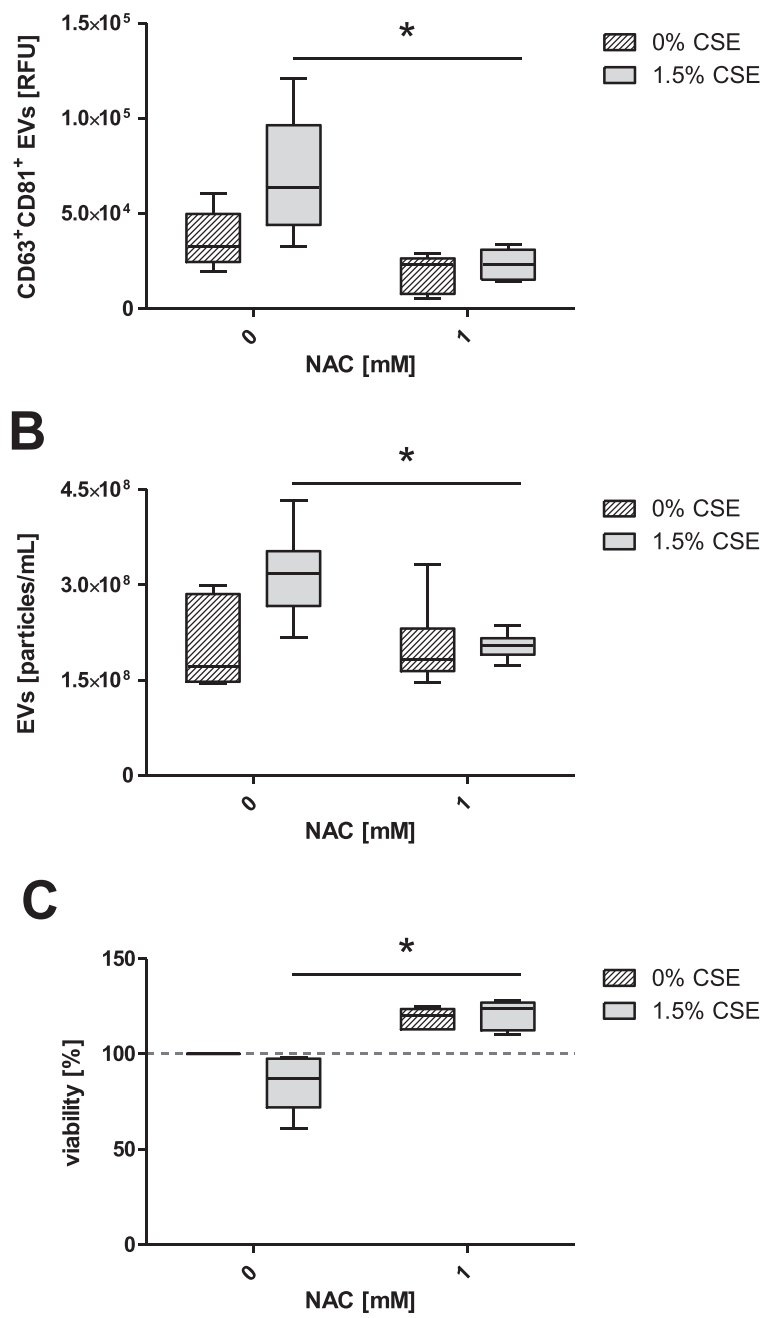

Fig. 3. Contribution of oxidative components to the effects of CSE on EV release and cell viability. BEAS-2B cells were exposed to $1.5 \%$ (v/v) PBS (control) or $1.5 \%$ (v/v) CSE for $24 \mathrm{~h}$ in the continuous presence of the thiol-group bearing antioxidant NAC. (A) Effect of NAC on CSE-induced EV release (CD63 ${ }^{+} \mathrm{CD} 81^{+}$bead-coupled flow cytometry), $n=6$. (B) Effect of NAC on CSE-induced EV release (TRPS), $n=6$. (C) Effect of NAC on cell viability (MTT assay), $\mathrm{n}=6$. All graphs show the median \pm IQR. Statistical differences were analyzed using Friedmann's test with Dunn's posthoc test ( $\left.{ }^{*} \mathrm{p}<0.05\right)$. Box and whisker plots indicate the median (line in box), 25th and 75th percentiles (outer lines of box) and the minimal and maximal values (whiskers).

Clinically, NAC is used in COPD patients as a mucolytic and antioxidant. While oral NAC treatment hardly increases NAC concentrations in the lung, it has been reported to result in a 1.7-fold increased GSH concentration in the epithelial lining fluid of patients with idiopathic pulmonary fibrosis, from $190 \mu \mathrm{M}$ to $320 \mu \mathrm{M}$ [29]. To determine whether CSE-induced EV release can be inhibited by such clinically relevant GSH concentrations, BEAS-2B cells were exposed to CSE in the continuous presence of different GSH concentrations. GSH concentration-dependently prevented EV induction by CSE (Fig. 4A) and restored cell viability (Fig. 4B). EV inhibition reached statistical significance at $125 \mu \mathrm{M} \mathrm{GSH}$ and was complete for $250 \mu \mathrm{M} \mathrm{GSH}$.

Among all CSE components, ROS such as $\mathrm{H}_{2} \mathrm{O}_{2}$ and reactive carbonyls such as acrolein can react with the thiol groups of both, GSH and NAC [30]. To determine whether these components contribute to CSE-induced exosome release, we exposed BEAS-2B cells for $24 \mathrm{~h}$ to either $\mathrm{H}_{2} \mathrm{O}_{2}$ or acrolein and measured the same parameters as after CSE exposure. $\mathrm{H}_{2} \mathrm{O}_{2}$ did not affect exosome release (Fig. 5A) at concentrations resulting in similar decreases in cell viability to CSE (Fig. 5B). In 

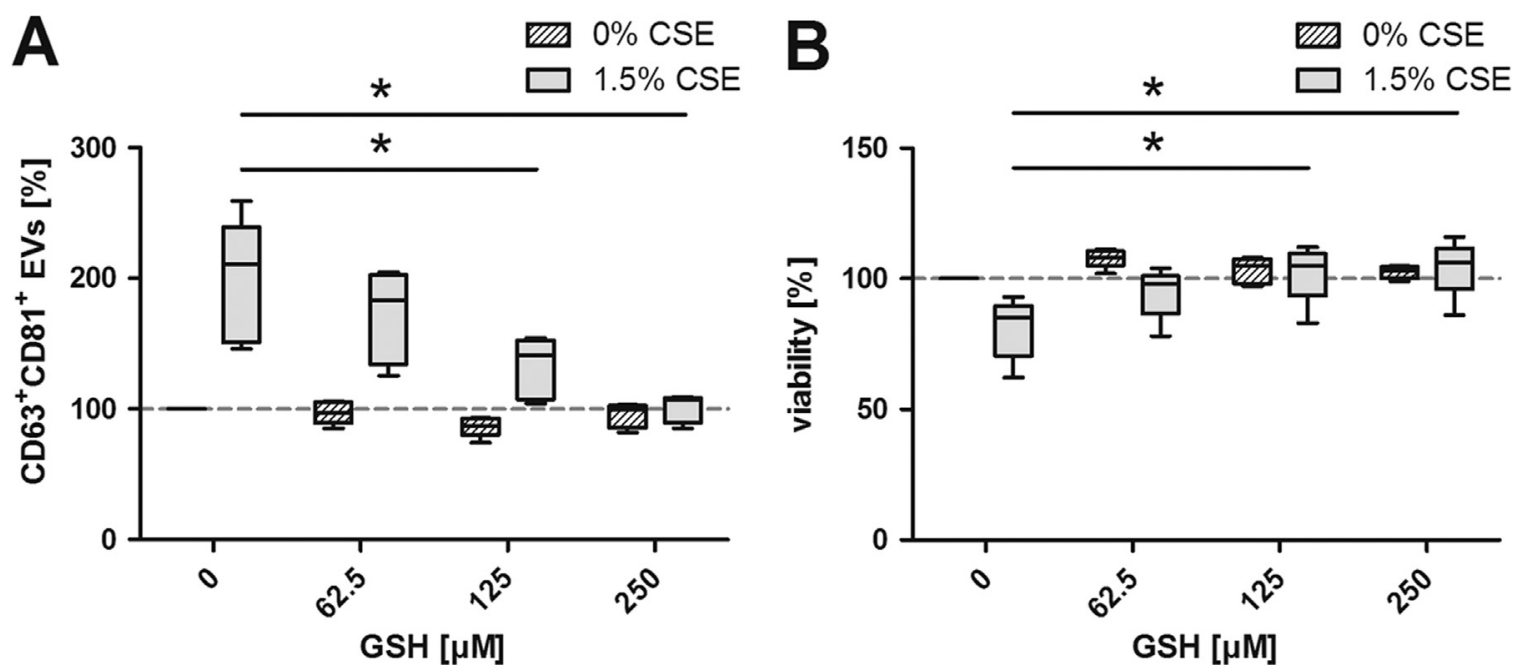

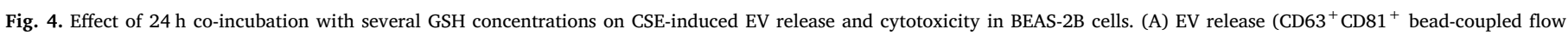

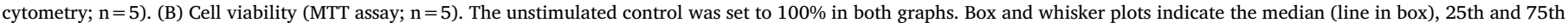

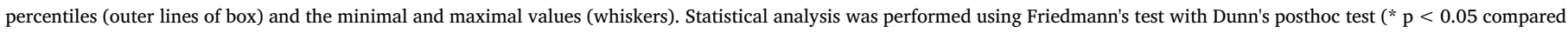
to $1.5 \%(\mathrm{v} / \mathrm{v}) \mathrm{CSE} / 0 \mu \mathrm{M} \mathrm{GSH})$.

contrast, acrolein augmented exosome release (Fig. 5C) already at concentrations that only mildly affected cell viability (Fig. 5D). Similar to the CSE-induced exosome release, the exosome induction by acrolein was completely prevented in the continuous presence of NAC (Fig. 5E) and cell viability was restored (Fig. 5F). This suggests that CSE and acrolein have a different effect on cellular thiols than $\mathrm{H}_{2} \mathrm{O}_{2}$, and that this difference may account for the EV induction.

\subsection{Reaction with exofacial thiols is sufficient to enhance EV release}

We next aimed to identify changes in cellular thiols that may mediate the exosome induction by CSE and acrolein. First, the intracellular concentrations of reduced GSH and its oxidation product GSSG were measured. While $24 \mathrm{~h}$ exposure to CSE or acrolein caused an increase in both, reduced GSH (Supplementary Fig. 1A, B) and its disulfide GSSG (Supplementary Fig. 1D, E), the increase in GSH was stronger as illustrated by an increasing GSH/GSSG ratio (Fig. 6A, B). Upon $\mathrm{H}_{2} \mathrm{O}_{2}$ exposure, GSH only increased slightly (Supplementary Fig. 1C), while GSSG (Supplementary Fig. 1F) and the GSH/GSSG ratio (Fig. 6C) remained unchanged. Next, the quantity of free thiol groups on the cell surface was assessed using the membrane impermeable thiol dye AFM. At concentrations of the three stimuli that were re-matched for their effect on cell viability, CSE and acrolein both lead to a concentration-dependent depletion of exofacial thiol groups (Fig. 6D, E), while $\mathrm{H}_{2} \mathrm{O}_{2}$ showed no effect (Fig. 6F). Thus, the oxidative stress caused by $24 \mathrm{~h}$ exposure to CSE or acrolein was compensated at the intracellular level, as illustrated by the increased GSH/GSSG ratio, but not on the cell surface, as illustrated by the depleted exofacial thiol groups. Finally, cells were exposed to CSE for $3 \mathrm{~h}$, followed by $24 \mathrm{~h}$ incubation in CSE-free medium, which does not result in increased EV release compared to unexposed cells (Fig. 1E). While GSH (Supplementary Fig. 1G), GSSG (Supplementary Fig. 1H), and the GSH/GSSG ratio (Fig. 7A) were increased similarly as during $24 \mathrm{~h}$ exposure to CSE, there was no effect on the exofacial thiol groups (Fig. 7B). Therefore, the EV induction is more likely mediated by the depletion of exofacial thiols than by the intracellular GSH response.

We next assessed whether depletion of exofacial thiol groups is sufficient to enhance EV release. For this purpose, we exposed the BEAS-2B cells to either DTNB or bacitracin for $24 \mathrm{~h}$. Both compounds have poor membrane permeability and block exofacial thiol groups by forming disulfide bonds [31-34]. Both, DTNB and bacitracin, induced EV release (Fig. 7A) without affecting cell viability (Fig. 7B). Bacitracin is known to inhibit the reductase function of protein disulfide isomerase
(PDI). However, PDI is not the only target of bacitracin [35]. For this reason, PDI reductase activity was inhibited more specifically using rutin [36] or the monoclonal anti-PDI antibody clone RL90. However, no effect on EV release was observed for either rutin or the PDI specific antibody at concentrations that have previously been shown to inhibit PDI activity $[36,37]$ and that were non-cytotoxic (Fig. 7A, B).

\section{Discussion}

Cigarette smoke causes serious damage to the airway epithelium $[38,39]$ and, in long term smokers, it forms an important risk for developing COPD [40]. In vitro, AEC exposed to CSE have been reported to release exosomes which induce myofibroblast differentiation [22] and cytokine secretion [21] in cells that have not been in direct contact with CSE. Therefore, it is conceivable that cigarette smoke-induced exosomes are involved in the pathogenesis of COPD. Understanding the biochemical mechanisms by which cigarette smoke influences exosome release by AEC, and how this can be prevented, could therefore be of clinical relevance.

The first objective of this study was to characterize the EV release after exposure of AEC to CSE in terms of quantity and EV properties. Using $\mathrm{CD} 3^{+} \mathrm{CD} 81^{+}$-bead coupled flow cytometry and the label-free TRPS technique, we found that CSE exposure enhances EV release concentration- and time-dependently. Based on their size and marker expression we classified both, control EVs and CSE-induced EVs, as exosomes. Our highly specific methods corroborate and extend a report from Moon et al. who found that CSE exposure of AEC increases the protein content of a $100,000 \times g$ ultracentrifugation pellet [21], which can be seen as a rough estimate for exosome quantity. Notably, we found that the increased exosome release upon CSE-exposure was paralleled by a concentration- and time-dependent decrease in cell viability. Yet, it is unlikely that cell death causes the increase in exosomes irrespective of the stimulus, since exposure to $\mathrm{H}_{2} \mathrm{O}_{2}$-concentrations with a similar impact on cell viability did not enhance exosome release. Additionally, the thiol-blocking compounds DTNB and bacitracin both enhanced EV release without affecting cell viability.

Our second objective was to identify the chemical trigger for CSEinduced exosome release. In line with previous research, we found that CSE is thiol-reactive as it depletes the free thiol groups of GSH in a direct reaction. Moreover, scavenging thiol-reactive compounds in CSE using the thiol-antioxidants NAC or GSH completely prevented the exosome induction. This implies that thiol-reactive compounds within CSE entirely account for the increased exosome release. Components of 

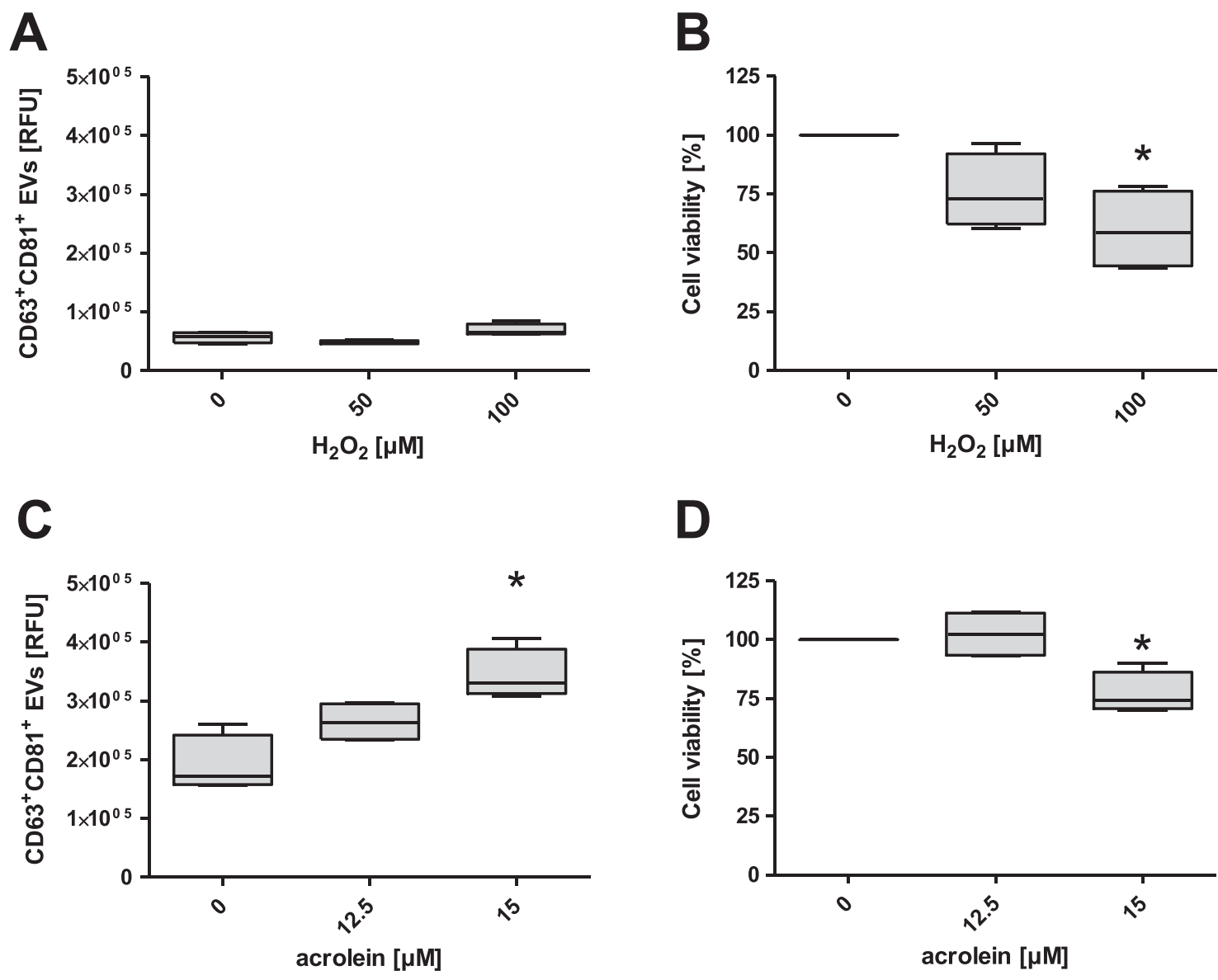

D
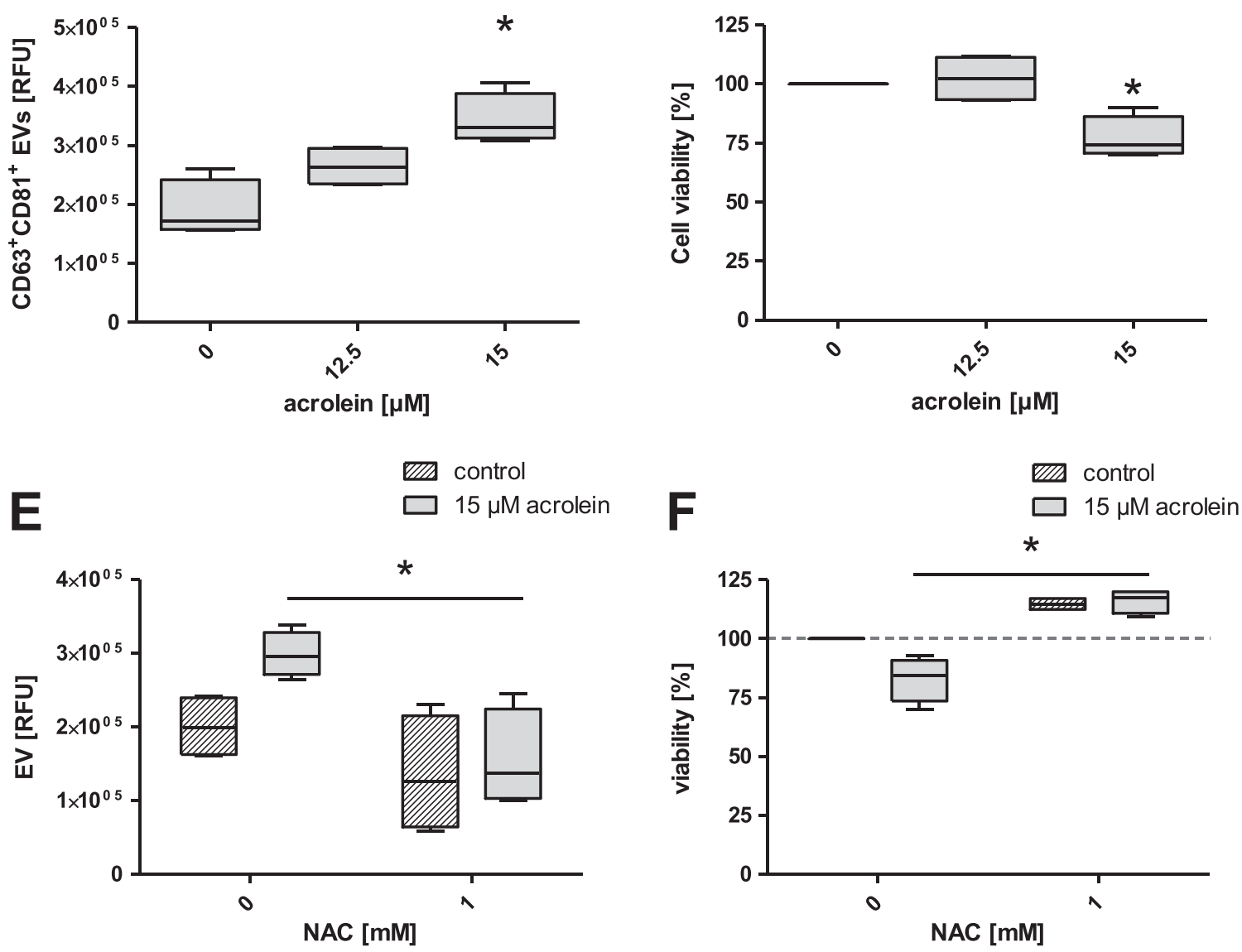

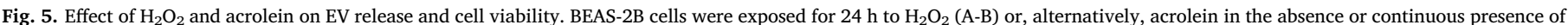

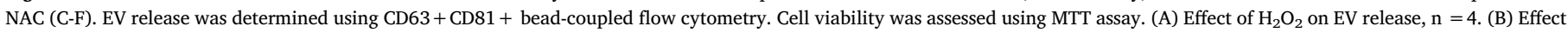

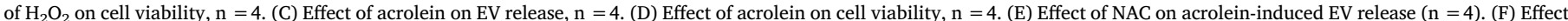

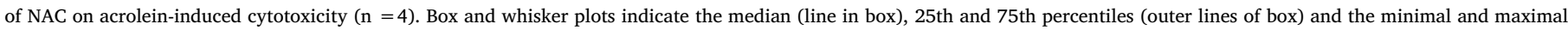

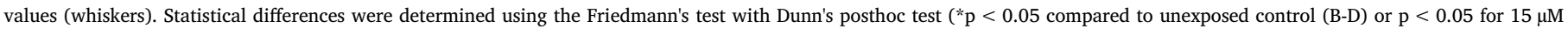
acrolein /1 mM NAC compared to $15 \mu \mathrm{M}$ acrolein /0 mM NAC (E)).

CSE that can react with thiol groups and thus can be neutralized by thiol-antioxidants comprise ROS such as $\mathrm{H}_{2} \mathrm{O}_{2}$, which cause disulfide bond formation [41,42]; and thiol-reactive carbonyls such as acrolein [43], which form adducts [44]. In our study, the cellular effects of CSE could not be mimicked by $\mathrm{H}_{2} \mathrm{O}_{2}$. Although the used $\mathrm{H}_{2} \mathrm{O}_{2}$ concentrations caused a similar decrease in cell viability to CSE, they had no effect on exosome release. This is in contrast to the findings of Hedlund et al. who have shown that lymphoma cells release more $\mathrm{CD} 63^{+} \mathrm{EVs}$ when exposed to $\mathrm{H}_{2} \mathrm{O}_{2}$ for $24 \mathrm{~h}$ [13]. Therefore, it may be cell-type specific whether an oxidative stimulus like $\mathrm{H}_{2} \mathrm{O}_{2}$ induces exosome release or not.

In contrast to $\mathrm{H}_{2} \mathrm{O}_{2}$, acrolein mimicked all cellular effects observed for CSE, including NAC-reversible induction of exosome release. Based on data from Lambert et al., who quantified acrolein in CSE, we estimate that the CSE concentration in our experiments $(1.5 \%(\mathrm{v} / \mathrm{v}))$ contains between 2.6 and $37.5 \mu \mathrm{M}$ acrolein [45]. This corresponds well with our experimental acrolein concentrations of 12.5-15 $\mu \mathrm{M}$. Moreover, the fold-change increase in exosome release was similar after 
A

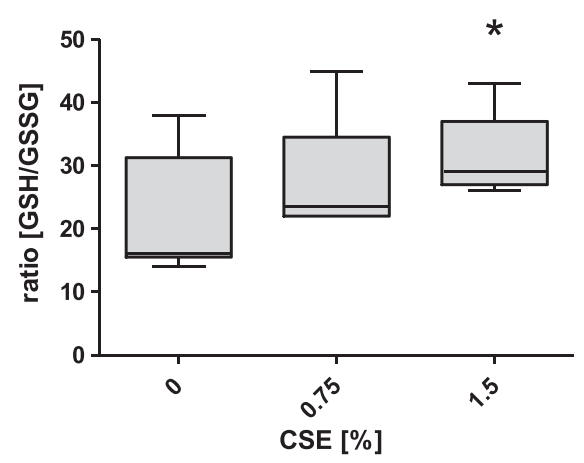

D

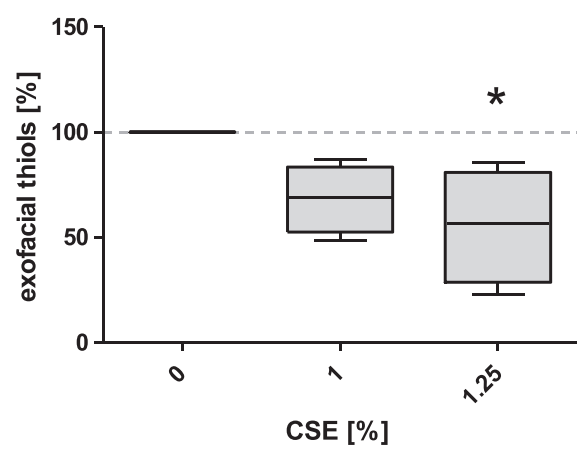

B

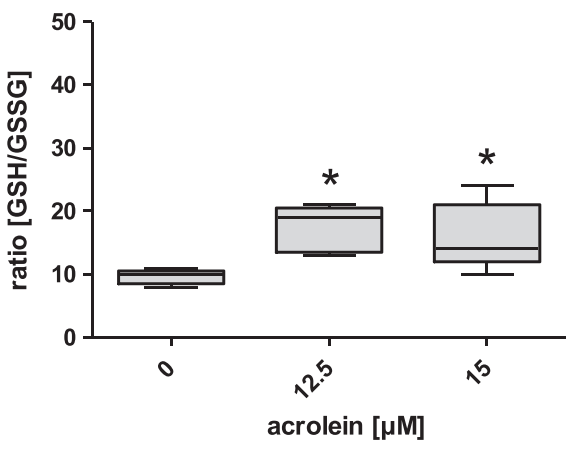

$\mathbf{E}$

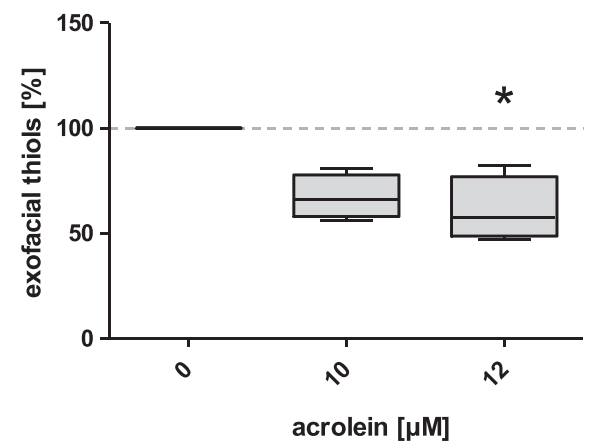

C

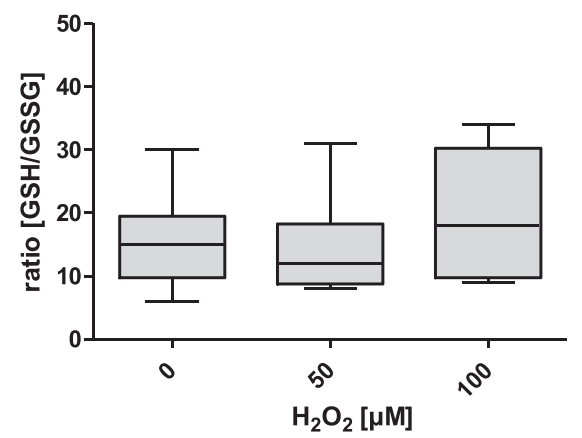

$\mathbf{F}$

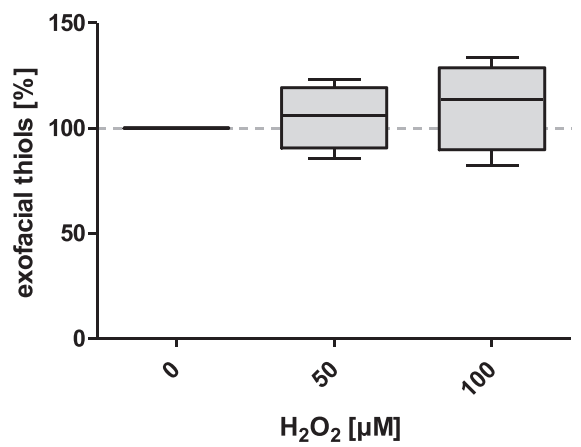

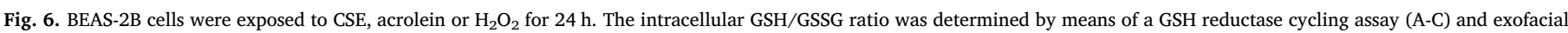

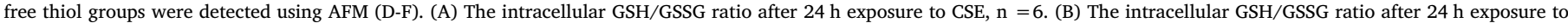

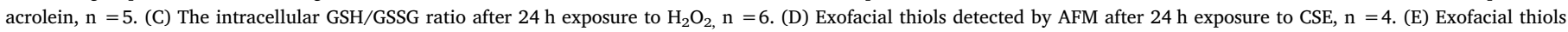

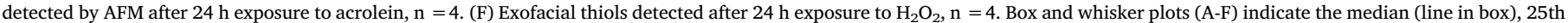

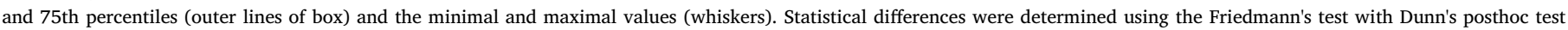
(* $\mathrm{p}<0.05$ compared to unexposed control).

exposure to $1.5 \%(\mathrm{v} / \mathrm{v}) \mathrm{CSE}$ and $15 \mu \mathrm{M}$ acrolein $(2.2 \pm 0.3$ fold vs. $1.9 \pm 0.3$ fold). In addition, NAC could completely restore exosome concentrations to the control level for both, CSE and acrolein exposure. Therefore, it is conceivable that acrolein accounts for the exosome induction upon CSE exposure. Intriguingly, acrolein and other thiolreactive carbonyls are not only present in CSE, but are also formed endogenously during inflammation and oxidative stress [46,47]. Thiolreactive carbonyls have been shown to be increased in COPD patients who have stopped smoking [9], and in other conditions characterized by inflammation and oxidative stress, such as diabetes and neuroinflammatory disorders [48-51]. Hence, they may serve as triggers for exosome release in these chronic inflammatory disorders. This is especially interesting as exosomes have been shown to play a pathological role in both, metabolic and neuroinflammatory diseases [52,53]. Moreover, NAC, which can prevent thiol-reactive carbonyl-induced exosome release has not only been attributed a protective role in COPD, but also in metabolic and neurological disorders [54,55].

Thirdly, we aimed to identify the cellular target that mediates the EV induction by CSE. Therefore, we first assessed how free thiol concentrations were affected at different subcellular locations. Intracellularly, $24 \mathrm{~h}$ exposure to CSE and acrolein, but not to $\mathrm{H}_{2} \mathrm{O}_{2}$, led to an overall increase in free thiols as indicated by an increased GSH/GSSG ratio. Such an upregulation of the endogenous antioxidant response has previously been reported for cells exposed to reactive carbonyls $[5,56]$. In spite of the excess of the oxidant-scavenging GSH inside the cell, free thiol groups on the cell surface were still depleted after $24 \mathrm{~h}$. This suggests the cellular target that mediates the EV induction by CSE may be located on the cell surface. Indeed, blocking exofacial thiols using either of two membrane-impermeable compounds, DTNB or bacitracin, was sufficient to induce exosome release with a similar fold-change to CSE. One target of bacitracin is cell surface-associated PDI [34,35]. Notably, PDI has previously been implied in EV release [37] and a recent study reports that CSE and acrolein, but not $\mathrm{H}_{2} \mathrm{O}_{2}$, inhibit PDI reductase activity [57]. However, in this study neither of two specific PDI reductase inhibitors, i.e. the flavonoid rutin [36] and the monoclonal antibody RL90 [37,58], elicited an increased exosome release. Thus, blocking thiol-disulfide exchange reactions on the cell surface may be the mechanism by which CSE enhances exosome release, but the precise molecular target remains to be elucidated. It is conceivable that exofacial thiol-depletion causes secondary intracellular changes, which then result in the exosome induction. However, we expect that the depletion of exofacial thiols directly results in the exosome induction as the induction already occurs within $30 \mathrm{~min}$ of exposure and requires the continuous presence of the stimulus. CSE may trigger the membrane fusion required for exosome release, as thiol-dependent mechanisms have long been known to regulate membrane fusion [59].

As CSE-induced exosomes have been attributed potentially detrimental functions [21,22], the ultimate objective of this study was also to evaluate whether exosome induction could be prevented by antioxidants at clinically relevant concentrations. Recent meta-analyses encourage the use of NAC in COPD patients, as high doses ( $\geq 1200 \mathrm{mg}$ / day orally) were found to be well tolerated and efficient in decreasing exacerbation frequency $[11,60]$ and to improve small airway function [10]. As the bioavailability of the unchanged NAC molecule is low, the beneficial effects are attributed to NAC serving as a precursor for GSH 

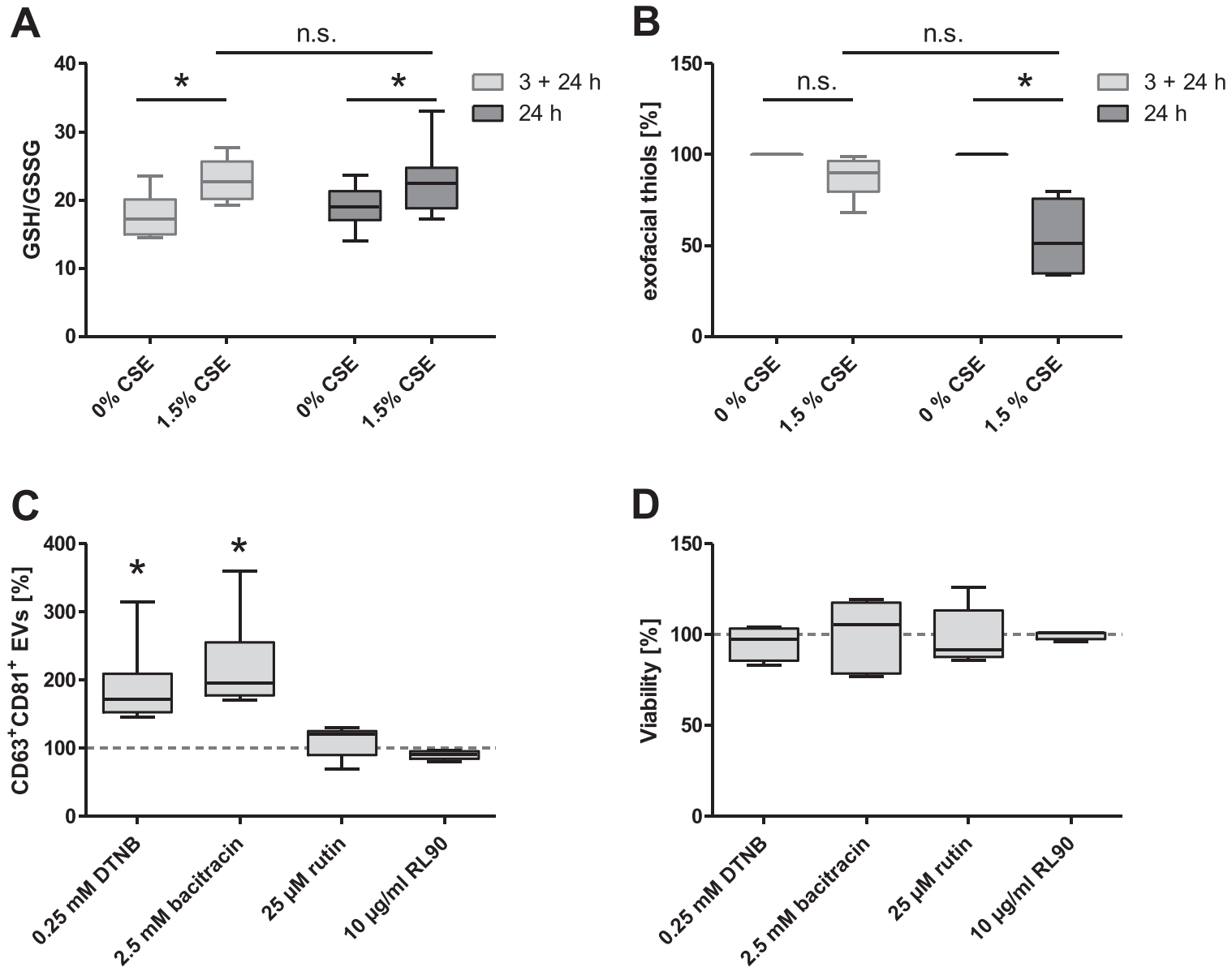

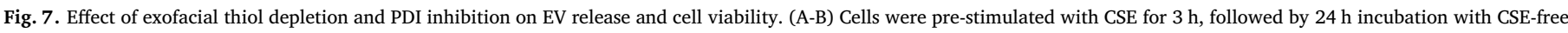

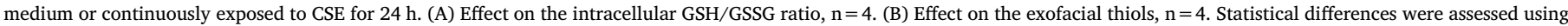

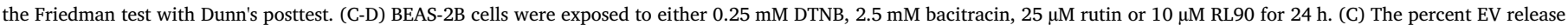

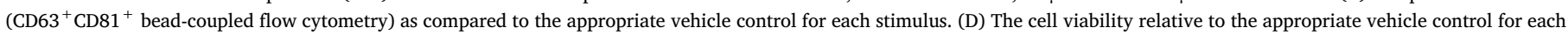

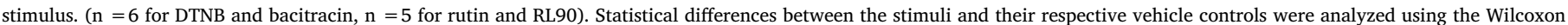

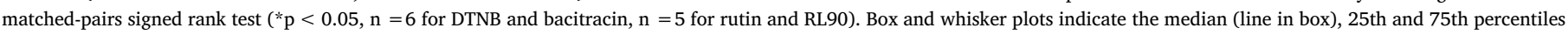
(outer lines of box) and the minimal and maximal values (whiskers).

[61]. GSH concentrations are severely decreased in the epithelial lining fluid (ELF) of COPD patients compared to healthy controls [61]. While it is not known if GSH in ELF of COPD patients can be restored by NAC treatment, patients with idiopathic pulmonary fibrosis have similarly decreased GSH concentrations $(190 \mu \mathrm{M}$ vs. $380 \mu \mathrm{M}$ in the control group) and these are restored to the normal level $(310 \mu \mathrm{M})$ by high dose NAC $(1800 \mathrm{mg} /$ day orally) [29]. Here, we found that GSH prevents CSE-induced EV release at $125-250 \mu \mathrm{M}$, which matches the concentration range observed in the IPF study. Thus, future studies should aim to explore whether inhibition of exosome release contributes to the protective outcome of oral NAC treatment in COPD patients.

A limitation of this study is that exposure to CSE in vitro is acute, whereas it is chronic cigarette smoking that forms the major risk factor for developing COPD. Additionally, it is currently impossible to match the in vitro CSE exposure to the in vivo CS exposure of the epithelium of smokers. However, it has been argued that acute CSE exposure in vitro is suitable to model changes in the naïve lung during the earliest phase of COPD development [62]. Nevertheless, to translate the in vitro findings of our study, it would be revealing to investigate exosome concentrations in bronchoalveolar lavage fluid or plasma of smokers and COPD patients compared with non-smoking control subjects. Although we did not address functional properties of CSE-induced exosomes, there is evidence from earlier studies that CSE-induced airway epithelialderived exosomes are involved in the pathogenesis of COPD by inducing of pro-inflammatory cytokines and profibrotic changes $[21,22]$. Therefore, it should also be studied whether exosomes from patients' body fluids contribute to the pathogenesis of COPD.

\section{Conclusion}

Our study reveals that CSE exposure enhances the exosome release by AEC. This is mediated by thiol-reactive compounds like the carbonyl acrolein, which may act by depleting extracellular free thiols. Thiolantioxidants like NAC and GSH inhibit exosome release induced by CSE or acrolein, which may contribute to the therapeutic benefits of NAC in COPD. These findings pave the way for future research investigating the role of cigarette smoke- and reactive carbonyl-induced exosomes in the pathogenesis of COPD and other chronic inflammatory diseases.

\section{Declaration of interest}

The authors declare no conflict of interest.

\section{Funding}

This project was funded by the Netherlands Organization for Scientific Research (NWO) grant number 022.003.011 with the title "NUTRIM NWO Graduate Program: Metabolism and chronic disease". The funding source was not involved in the study design; in the 
collection, analysis and interpretation of data; in the writing of the report; and in the decision to submit the article for publication.

\section{Acknowledgements}

The authors would like to thank Hans Duimel for performing the cryo-transmission electron microscopy recordings and Marie-José Drittij for performing the glutathione reductase cycling assay. They would also like to thank Gert Grauls for her general support in the lab and Mayk Lucchesi for designing the graphical abstract.

\section{Appendix A. Supporting information}

Supplementary data associated with this article can be found in the online version at doi:10.1016/j.freeradbiomed.2017.03.026.

\section{References}

[1] T.S. Hallstrand, T.L. Hackett, W.A. Altemeier, G. Matute-Bello, P.M. Hansbro, D.A. Knight, Airway epithelial regulation of pulmonary immune homeostasis and inflammation, Clin. Immunol. 151 (2014) 1-15.

[2] M.R. Stampfli, G.P. Anderson, How cigarette smoke skews immune responses to promote infection, lung disease and cancer, Nat. Rev. Immunol. 9 (2009) 377-384.

[3] A. Valavanidis, T. Vlachogianni, K. Fiotakis, Tobacco smoke: involvement of reactive oxygen species and stable free radicals in mechanisms of oxidative damage, carcinogenesis and synergistic effects with other respirable particles, Int. J. Environ. Res. Public Health 6 (2009) 445-462.

[4] W.A. Pryor, K. Stone, Oxidants in cigarette smoke. radicals, hydrogen peroxide, peroxynitrate, and peroxynitrite, Ann. N. Y. Acad. Sci. 686 (1993) 12-27 (discussion 27-18).

[5] M.M. Sthijns, M.J. Randall, A. Bast, G.R. Haenen, Adaptation to acrolein through upregulating the protection by glutathione in human bronchial epithelial cells: the materialization of the hormesis concept, Biochem. Biophys. Res. Commun. 446 (2014) 1029-1034.

[6] G.R. Haenen, N.P. Vermeulen, J.N. Tai Tin Tsoi, H.M. Ragetli, H. Timmerman, A. Blast, Activation of the microsomal glutathione-S-transferase and reduction of the glutathione dependent protection against lipid peroxidation by acrolein, Biochem. Pharmacol. 37 (1988) 1933-1938.

[7] L. Zuo, F. He, G.G. Sergakis, M.S. Koozehchian, J.N. Stimpfl, Y. Rong, P.T. Diaz, T.M. Best, Interrelated role of cigarette smoking, oxidative stress, and immune response in COPD and corresponding treatments, Am. J. Physiol. Lung Cell. Mol. Physiol. 307 (2014) L205-L218.

[8] P.A. Kirkham, P.J. Barnes, Oxidative stress in COPD, Chest 144 (2013) 266-273.

[9] H.S. Deshmukh, C. Shaver, L.M. Case, M. Dietsch, S.C. Wesselkamper, W.D. Hardie, T.R. Korfhagen, M. Corradi, J.A. Nadel, M.T. Borchers, G.D. Leikauf, Acroleinactivated matrix metalloproteinase 9 contributes to persistent mucin production, Am. J. Respir. Cell Mol. Biol. 38 (2008) 446-454.

[10] H.N. Tse, C.Z. Tseng, Update on the pathological processes, molecular biology, and clinical utility of N-acetylcysteine in chronic obstructive pulmonary disease, Int. J. Chronic Obstr. Pulm. Dis. 9 (2014) 825-836.

[11] M. Cazzola, L. Calzetta, C. Page, J. Jardim, A.G. Chuchalin, P. Rogliani, M.G. Matera, Influence of N-acetylcysteine on chronic bronchitis or COPD exacerbations: a meta-analysis, Eur. Respir. Rev. 24 (2015) 451-461.

[12] M. Eldh, K. Ekstrom, H. Valadi, M. Sjostrand, B. Olsson, M. Jernas, J. Lotvall, Exosomes communicate protective messages during oxidative stress; possible role of exosomal shuttle RNA, PLoS One 5 (2010) e15353.

[13] M. Hedlund, O. Nagaeva, D. Kargl, V. Baranov, L. Mincheva-Nilsson, Thermal- and oxidative stress causes enhanced release of NKG2D ligand-bearing immunosuppressive exosomes in leukemia/lymphoma T and B cells, PLoS One 6 (2011) e16899.

[14] K. Szabo-Taylor, B. Ryan, X. Osteikoetxea, T.G. Szabo, B. Sodar, M. Holub, A. Nemeth, K. Paloczi, E. Pallinger, P. Winyard, E.I. Buzas, Oxidative and other posttranslational modifications in extracellular vesicle biology, Semin. Cell Dev. Biol. 40 (2015) 8-16.

[15] R.M. Johnstone, M. Adam, J.R. Hammond, L. Orr, C. Turbide, Vesicle formation during reticulocyte maturation. Association of plasma membrane activities with released vesicles (exosomes), J. Biol. Chem. 262 (1987) 9412-9420.

[16] R. Safaei, B.J. Larson, T.C. Cheng, M.A. Gibson, S. Otani, W. Naerdemann, S.B. Howell, Abnormal lysosomal trafficking and enhanced exosomal export of cisplatin in drug-resistant human ovarian carcinoma cells, Mol. Cancer Ther. 4 (2005) 1595-1604.

[17] P.D. Robbins, A.E. Morelli, Regulation of immune responses by extracellular vesicles, Nat. Rev. Immunol. 14 (2014) 195-208.

[18] S.J. Gould, G. Raposo, As we wait: coping with an imperfect nomenclature for extracellular vesicles, J. Extracell. Vesicles 2 (2013).

[19] C. Gordon, K. Gudi, A. Krause, R. Sackrowitz, B.G. Harvey, Y. Strulovici-Barel, J.G. Mezey, R.G. Crystal, Circulating endothelial microparticles as a measure of early lung destruction in cigarette smokers, Am. J. Respir. Crit. Care Med. 184 (2011) 224-232.

[20] T. Takahashi, S. Kobayashi, N. Fujino, T. Suzuki, C. Ota, M. He, M. Yamada,
S. Suzuki, M. Yanai, S. Kurosawa, M. Yamaya, H. Kubo, Increased circulating endothelial microparticles in COPD patients: a potential biomarker for COPD exacerbation susceptibility, Thorax 67 (2012) 1067-1074.

[21] H.G. Moon, S.H. Kim, J. Gao, T. Quan, Z. Qin, J.C. Osorio, I.O. Rosas, M. Wu, Y. Tesfaigzi, Y. Jin, CCN1 secretion and cleavage regulate the lung epithelial cell functions after cigarette smoke, Am. J. Physiol. Lung Cell. Mol. Physiol. 307 (2014) L326-L337.

[22] Y. Fujita, J. Araya, S. Ito, K. Kobayashi, N. Kosaka, Y. Yoshioka, T. Kadota, H. Hara, K. Kuwano, T. Ochiya, Suppression of autophagy by extracellular vesicles promotes myofibroblast differentiation in COPD pathogenesis, J. Extracell. Vesicles 4 (2015) 28388.

[23] I. Rahman, A. Kode, S.K. Biswas, Assay for quantitative determination of glutathione and glutathione disulfide levels using enzymatic recycling method, Nat. Protoc. 1 (2006) 3159-3165.

[24] M. Ostrowski, N.B. Carmo, S. Krumeich, I. Fanget, G. Raposo, A. Savina, C.F. Moita, K. Schauer, A.N. Hume, R.P. Freitas, B. Goud, P. Benaroch, N. Hacohen, M. Fukuda, C. Desnos, M.C. Seabra, F. Darchen, S. Amigorena, L.F. Moita, C. Thery, Rab27a and Rab27b control different steps of the exosome secretion pathway, Nat. Cell Biol. 12 (2010) 19-30 (sup pp 11-13).

[25] A.N. Kapustin, M.L. Chatrou, I. Drozdov, Y. Zheng, S.M. Davidson, D. Soong, M. Furmanik, P. Sanchis, R.T. De Rosales, D. Alvarez-Hernandez, R. Shroff, X. Yin, K. Muller, J.N. Skepper, M. Mayr, C.P. Reutelingsperger, A. Chester, S. Bertazzo, L.J. Schurgers, C.M. Shanahan, Vascular smooth muscle cell calcification is mediated by regulated exosome secretion, Circ. Res. 116 (2015) 1312-1323.

[26] A. Cvjetkovic, J. Lotvall, C. Lasser, The influence of rotor type and centrifugation time on the yield and purity of extracellular vesicles, J. Extracell. Vesicles 3 (2014).

[27] C. Thery, M. Ostrowski, E. Segura, Membrane vesicles as conveyors of immune responses, Nat. Rev. Immunol. 9 (2009) 581-593.

[28] K.W. Witwer, E.I. Buzas, L.T. Bemis, A. Bora, C. Lasser, J. Lotvall, E.N. Nolte-'t Hoen, M.G. Piper, S. Sivaraman, J. Skog, C. Thery, M.H. Wauben, F. Hochberg, Standardization of sample collection, isolation and analysis methods in extracellular vesicle research, J. Extracell. Vesicles 2 (2013).

[29] A. Meyer, R. Buhl, H. Magnussen, The effect of oral N-acetylcysteine on lung glutathione levels in idiopathic pulmonary fibrosis, Eur. Respir. J. 7 (1994) $431-436$.

[30] J.B. Wooten, S. Chouchane, T.E. McGrath, Tobacco Smoke Constituents Affecting Oxidative Stress, in: Barry B. Halliwell, Henrik E. Poulsen (Eds.), Cigarette Smoke and Oxidative Stress, Springer, Heidelberg, 2006, pp. 5-46.

[31] G.L. Ellman, Tissue sulfhydryl groups, Arch. Biochem. Biophys. 82 (1959) 70-77.

[32] J. Reglinski, S. Hoey, W.E. Smith, R.D. Sturrock, Cellular response to oxidative stress at sulfhydryl group receptor sites on the erythrocyte membrane, J. Biol. Chem. 263 (1988) 12360-12366.

[33] R. Mandel, H.J. Ryser, F. Ghani, M. Wu, D. Peak, Inhibition of a reductive function of the plasma membrane by bacitracin and antibodies against protein disulfideisomerase, Proc. Natl. Acad. Sci. USA 90 (1993) 4112-4116.

[34] N. Dickerhof, T. Kleffmann, R. Jack, S. McCormick, Bacitracin inhibits the reductive activity of protein disulfide isomerase by disulfide bond formation with free cysteines in the substrate-binding domain, FEBS J. 278 (2011) 2034-2043.

[35] A.R. Karala, L.W. Ruddock, Bacitracin is not a specific inhibitor of protein disulfide isomerase, FEBS J. 277 (2010) 2454-2462.

[36] R. Jasuja, F.H. Passam, D.R. Kennedy, S.H. Kim, L. van Hessem, L. Lin, S.R. Bowley, S.S. Joshi, J.R. Dilks, B. Furie, B.C. Furie, R. Flaumenhaft, Protein disulfide isomerase inhibitors constitute a new class of antithrombotic agents, J. Clin. Investig. 122 (2012) 2104-2113.

[37] C. Furlan-Freguia, P. Marchese, A. Gruber, Z.M. Ruggeri, W. Ruf, P2 $\times 7$ receptor signaling contributes to tissue factor-dependent thrombosis in mice, J. Clin. Investig. 121 (2011) 2932-2944.

[38] A.J. Thorley, T.D. Tetley, Pulmonary epithelium, cigarette smoke, and chronic obstructive pulmonary disease, Int. J. Chronic Obstr. Pulm. Dis. 2 (2007) 409-428.

[39] T. Nyunoya, Y. Mebratu, A. Contreras, M. Delgado, H.S. Chand, Y. Tesfaigzi, Molecular processes that drive cigarette smoke-induced epithelial cell fate of the lung, Am. J. Respir. Cell Mol. Biol. 50 (2014) 471-482.

[40] S. Salvi, Tobacco smoking and environmental risk factors for chronic obstructive pulmonary disease, Clin. Chest Med. 35 (2014) 17-27.

[41] C.C. Winterbourn, D. Metodiewa, Reactivity of biologically important thiol compounds with superoxide and hydrogen peroxide, Free Radic. Biol. Med. 27 (1999) 322-328.

[42] W. Droge, Free radicals in the physiological control of cell function, Physiol. Rev. 82 (2002) 47-95.

[43] B. Halliwell, H.E. Poulsen, Cigarette Smoke and Oxidative Stress, Springer, 2006.

[44] M. van der Toorn, M.P. Smit-de Vries, D.J. Slebos, H.G. de Bruin, N. Abello, A.J. van Oosterhout, R. Bischoff, H.F. Kauffman, Cigarette smoke irreversibly modifies glutathione in airway epithelial cells, Am. J. Physiol. Lung Cell. Mol. Physiol. 293 (2007) L1156-L1162.

[45] C. Lambert, J. McCue, M. Portas, Y. Ouyang, J. Li, T.G. Rosano, A. Lazis, B.M. Freed, Acrolein in cigarette smoke inhibits T-cell responses, J. Allergy Clin. Immunol. 116 (2005) 916-922.

[46] K. Bein, G.D. Leikauf, Acrolein - a pulmonary hazard, Mol. Nutr. Food Res. 55 (2011) 1342-1360.

[47] J. Mano, Reactive carbonyl species: their production from lipid peroxides, action in environmental stress, and the detoxification mechanism, Plant. Physiol. Biochem. 59 (2012) 90-97.

[48] E. Hopps, G. Caimi, Protein oxidation in metabolic syndrome, Clin. Invest. Med. 36 (2013) E1-E8.

[49] C. Karasu, Glycoxidative stress and cardiovascular complications in experimentallyinduced diabetes: effects of antioxidant treatment, Open Cardiovasc. Med. J. 4 
(2010) 240-256.

[50] M. Arai, M. Miyashita, A. Kobori, K. Toriumi, Y. Horiuchi, M. Itokawa, Carbonyl stress and schizophrenia, Psychiatry Clin. Neurosci. 68 (2014) 655-665.

[51] R.M. Adibhatla, J.F. Hatcher, Lipid oxidation and peroxidation in CNS health and disease: from molecular mechanisms to therapeutic opportunities, Antioxid. Redox Signal. 12 (2010) 125-169.

[52] A.J. Lakhter, E.K. Sims, Minireview: emerging roles for extracellular vesicles in diabetes and related metabolic disorders, Mol. Endocrinol. 29 (2015) 1535-1548.

[53] A. Gupta, L. Pulliam, Exosomes as mediators of neuroinflammation, J. Neuroinflammation. 11 (2014) 68.

[54] M.M. Lasram, I.B. Dhouib, A. Annabi, S. El Fazaa, N. Gharbi, A review on the possible molecular mechanism of action of $\mathrm{N}$-acetylcysteine against insulin resistance and type-2 diabetes development, Clin. Biochem. 48 (2015) 1200-1208.

[55] Deepmala, J. Slattery, N. Kumar, L. Delhey, M. Berk, O. Dean, C. Spielholz, R. Frye, Clinical trials of $\mathrm{N}$-acetylcysteine in psychiatry and neurology: a systematic review, Neurosci. Biobehav. Rev. 55 (2015) 294-321.

[56] R. Tirumalai, T. Rajesh Kumar, K.H. Mai, S. Biswal, Acrolein causes transcriptional induction of phase II genes by activation of Nrf2 in human lung type II epithelial (A549) cells, Toxicol. Lett. 132 (2002) 27-36.
[57] H. Kenche, Z.W. Ye, K. Vedagiri, D.M. Richards, X.H. Gao, K.D. Tew, D.M. Townsend, A. Blumental-Perry, Adverse outcomes associated with cigarette smoke radicals related to damage to protein-disulfide isomerase, J. Biol. Chem. 291 (2016) 4763-4778.

[58] K. Jurk, J. Lahav, V.A.N.A. H, M.F. Brodde, J.R. Nofer, B.E. Kehrel, Extracellular protein disulfide isomerase regulates feedback activation of platelet thrombin generation via modulation of coagulation factor binding, J. Thromb. Haemost. 9 (2011) 2278-2290.

[59] D.A. Sanders, Sulfhydryl involvement in fusion mechanisms, Sub-Cell. Biochem. 34 (2000) 483-514

[60] Y. Shen, W. Cai, S. Lei, Z. Zhang, Effect of high/low dose N-acetylcysteine on chronic obstructive pulmonary disease: a systematic review and meta-analysis, J. Chronic Obstr. Pulm. Dis. 11 (2014) 351-358.

[61] N.S. Gould, B.J. Day, Targeting maladaptive glutathione responses in lung disease, Biochem. Pharmacol. 81 (2011) 187-193.

[62] H. van der Vaart, D.S. Postma, W. Timens, N.H. ten Hacken, Acute effects of cigarette smoke on inflammation and oxidative stress: a review, Thorax 59 (2004) 713-721. 